\title{
Pertamax Quality: Study of Customer Satisfaction Through Importance Performance Analysis Method in MOR 4 Semarang
}

\author{
Hanifa Azzahro $^{1 *}$, Andian Ari Istiningrum ${ }^{1}$ \\ ${ }^{1}$ Department of Oil and Gas Logistics, Politeknik Energi dan Mineral AKAMIGAS Cepu, Indonesia \\ "Corresponding author. Email: azzahrohanifa@gmail.com
}

\begin{abstract}
Pertamax is one of the fuels sold by Pertamina with Research Octanne Number 92. Pertamax is claimed as the fuel having higher quality than Premium and Pertalite because of its good performance and environmentally friendly. However, the sale of Pertamax in Semarang has been stagnant for the last five years. Therefore, it is necessary to determine the way to improve Pertamax quality to enhance the sale of Pertamax. The purpose of this research was to analyse the quality of Pertamax based on customer satisfaction using Importance Performance Analysis method. The population in this research was customers of Pertamax in Semarang with a sample of 100 respondents taken using incidental sampling method. The result showed that Pertamax customers in Semarang are very satisfied toward its quality with level of satisfaction arrives at $87 \%$. Then, it is advisable that Pertamax quality should be improved due the important aspects perceived by Pertamax customers. Based on the perspective of the customers, the performance of Pertamax should be felt by customers since the first use of Pertamax. In addition, Pertamina should have a way to convince customers that Pertamax is more efficient than Premium and Pertalite. Last, Gas station operators should be more friendly, polite, and responsive in serving customers.
\end{abstract}

Keywords: Pertamax, customer satisfaction, IPA

\section{INTRODUCTION}

Customer satisfaction today holds an important key in determining the success of marketing strategies that were implemented by the company. Customer satisfaction is considered to be able to represent how feasible a product can be accepted by communities and is perceived as one of the dimensions of market performance [1]. Increased customer satisfactions potentially enhance sales growth and market share as a result of repeat purchases; whereas customer dissatisfaction may lead to a number of risks, such as customer complaints, consumer agency protest, government intervention, competitors' reactions, and new substitute product entry to the market.

Pertamina is one of the companies providing fuel oil in Indonesia. Pertamina has a variety of fuel products with various specifications that are sold at varying prices. Competition among companies requires Pertamina to always improve the quality of products sold to the customers. One of the products sold by Pertamina is Pertamax. Pertamax is a fuel that is usually used by gasoline-engine vehicles. Pertamax has a Research Octane Number (RON) 92 which is higher than the specification set by the Director General of Oil and Gas (RON 91) and higher than Premium (RON 88) and Pertalite (RON 90). Pertamax is recommended for vehicle engines that have applied technology equivalent to electronic fuel injection and catalytic converters. Vehicles with these technologies allow vehicles to be more environmentally friendly. The higher RON enables to optimize engine performance, reduce engine damage, and make efficient the use of fuel so that environmental sustainability can be maintained.

A higher RON number creates Pertamax to have better quality than Premium and Pertalite. As a consequence, the selling price of Pertamax is also higher than Premium and Pertalite. Although the price of Pertamax is more expensive than Premium and Pertalite, Pertamax still has its own market share. Pertamax's market share increased in early 2017 where $44 \%$ of Premium costumers switched to using Pertalite and Pertamax [2].

At present, Pertamax can be found easily in almost fuel stations. In addition, Pertamina often holds promotions to increase Pertamax sales, such as Berkah Energi Pertamina program during 2018 and 2019. This program has succeeded in reducing Premium consumption by $20 \%$ [3]. However, Pertamina decided to increase the selling price of Pertamax from IDR 9500 to IDR 10,400 when Berkah Energi Pertamina program was still ongoing [4]. As a result, the price difference between Pertamax and Pertalite/Premium has become even higher. The price increase may cause Pertamax consumer to switch back to using Pertalite and Premium [5]. Therefore, Pertamina needs to maintain and increase Pertamax market share by increasing customer satisfaction toward Pertamax quality. The quality of the products offered by Pertamax is expected to be able to raise public awareness to switch to using fuel with quality that is in accordance with the technological developments.

To realize the expectation that Pertamax's market share will increase, it is necessary to measure the level of customer 
satisfaction toward Pertamax quality. The Importance Performance Analysis (IPA) method is one method that can be used to measure the level of customer satisfaction with the performance of company where the results of the analysis can be used to improve performance [6]. The IPA method provides information relating to what factors the customer believes greatly affect their satisfaction and what factors the customer thinks should be improved by the company.

Based on those backgrounds, this study was conducted to determine the level of customer satisfaction toward Pertamax quality and to improve the quality of Pertamax based on customer satisfaction that was measured using IPA method.

Table 1 Research variables

\section{METHOD}

\subsection{Research Variables}

This research was a qualitative study conducted in Pertamina Marketing Operating Region (MOR) 4 at Semarang City. Table 1 shows the variables used in this research.

\subsection{Population and Sample}

Population used in this research was the end customer of Pertamax in Semarang city. Among these end customers, 100 customers were chosen as the sample of this research. The number of samples was calculated using Lemeshow formula with $95 \%$ degree of confident and $10 \%$ sampling error. The sample was taken through incidental sampling in five fuel stations in Semarang City.

\subsection{Data Collection}

This research used survey as the method to collect data. Table 2 shows the questionnaire that was used to collect data from respondents. Each positive item in the questionnaire was measured by Likert scale that consisted of five scales from really bad performance to really good performance for measuring actual Pertamax performance based on the customer perception and from not really important to really important for measuring customer expectation from using Pertamax.

Table 2 Questionnaire indicators

\begin{tabular}{|c|c|c|}
\hline Indicators & Attributes & Item \\
\hline \multirow[t]{2}{*}{ Performance } & The influence of Pertamax toward vehicle engine performance & 1 \\
\hline & The influence of RON toward pull of a vehicle engine & 2 \\
\hline \multirow[t]{3}{*}{ Features } & The speed of Pertamax filling up process & 3 \\
\hline & The efficiency of expenditure by using Pertamax & 4 \\
\hline & The publication of Pertamax specification & 5 \\
\hline \multirow[t]{2}{*}{ Reliability } & The conformity of Pertamax specifications to vehicle engine performance & 6 \\
\hline & The ease in getting Pertamax & 7 \\
\hline \multirow[t]{2}{*}{ Conformance } & The Pertamax ability to maintain vehicle engines & 8,10 \\
\hline & The Pertamax ability to maintain sustainability of environment & 9 \\
\hline \multirow[t]{2}{*}{ Durability } & The efficiency of using Pertamax & 11 \\
\hline & The emission vehicle engines using Pertamax & 12 \\
\hline \multirow[t]{2}{*}{ Service Ability } & The service provided by customer care & 13 \\
\hline & The service provided by fuel station operator & $14,15,16$ \\
\hline Aesthetic & The physical characteristics of Pertamax & 17,18 \\
\hline Perceived & The customer pride of using Pertamax & 19 \\
\hline Quality & The customer convenience in using Pertamax & 20 \\
\hline
\end{tabular}


item is higher than 0.361 , therefore it can be concluded that the items in the questionnaire are all valid. Reliability of the questionnaire was tested using Cronbach's Alpha test. It can be seen in table 5 that both questionnaires are reliable since the value of Cronbach's Alpha is higher than 0.60 [8].

Table 4 Validity test result

while:

The data was analysed using Importance Performance Analysis (IPA) method. As in Martila \& James [7], the steps to conduct IPA consist of:

a. Calculate the level of customer satisfaction.

$$
T k i=\frac{X i}{Y i} \times 100 \%
$$

$\mathrm{Tki}=$ the level of customer satisfaction

$\mathrm{Xi}=$ score of actual Pertamax performance

$\mathrm{Yi}=$ score of customer expectation in using Pertamax

As in Sugiyono [8], Table 3 shows the criteria used to classify the level of customer satisfaction.

Table 3 Customer satisfaction level

\begin{tabular}{|lc|}
\hline \multicolumn{1}{|c|}{ Score } & Level (\%) \\
\hline Very satisfied & $81-100$ \\
Satisfied & $66-80$ \\
Moderate & $51-65$ \\
Not satisfied & $35-50$ \\
Very dissatisfied & $0-34$ \\
\hline
\end{tabular}

b. Calculating the average score of Pertamax actual performance and customer expectation of using Pertamax

$$
\overline{\bar{X}}=\frac{\sum_{\bar{i}=1}^{W} \overline{X_{l}}}{K} ; \quad \overline{\bar{Y}}=\frac{\sum_{\bar{i}=1}^{W} \overline{Y_{l}}}{K}
$$

while:

$\mathrm{K}=$ total attributes

c. Plotting $\overline{\overline{\mathrm{X}}}$ and $\overline{\overline{\mathrm{Y}}}$ into Matrix Importance Performance Analysis

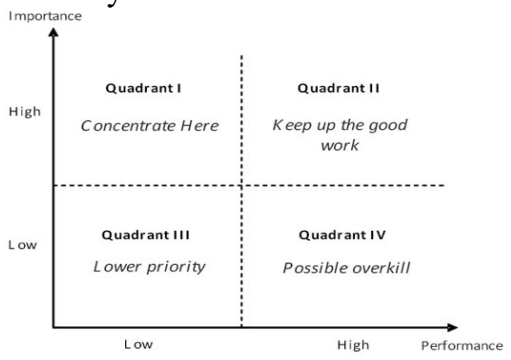

Figure 1 Matrix Importance Performance Analysis

\section{RESULTS AND DISCUSSION}

\subsection{Validity And Reliability Tests}

Pilot test was conducted to 30 respondents out of 100 respondents that become the research sample. The validity of questionnaire was tested using Pearson Product Moment and the result is shown at table 4 . For 30 respondents, the score of $\mathrm{R}$ table with $5 \%$ significance value is 0.361 . It can be seen from table 4 that the score of $\mathrm{R}$ calculation in each

\begin{tabular}{|ccccc|}
\hline Item & $\begin{array}{c}\mathbf{R} \\
\text { Table }\end{array}$ & $\begin{array}{c}\mathbf{R} \\
\text { Performance }\end{array}$ & $\begin{array}{c}\mathbf{R} \\
\text { Expectation }\end{array}$ & Status \\
\hline 1 & 0.361 & 0.451 & 0.463 & Valid \\
2 & 0.361 & 0.596 & 0.480 & Valid \\
3 & 0.361 & 0.512 & 0.423 & Valid \\
4 & 0.361 & 0.788 & 0.686 & Valid \\
5 & 0.361 & 0.592 & 0.501 & Valid \\
6 & 0.361 & 0.646 & 0.506 & Valid \\
7 & 0.361 & 0.395 & 0.581 & Valid \\
8 & 0.361 & 0.657 & 0.727 & Valid \\
9 & 0.361 & 0.703 & 0.531 & Valid \\
10 & 0.361 & 0.578 & 0.432 & Valid \\
11 & 0.361 & 0.806 & 0.690 & Valid \\
12 & 0.361 & 0.673 & 0.743 & Valid \\
13 & 0.361 & 0.592 & 0.607 & Valid \\
14 & 0.361 & 0.554 & 0.592 & Valid \\
15 & 0.361 & 0.499 & 0.604 & Valid \\
16 & 0.361 & 0.561 & 0.625 & Valid \\
17 & 0.361 & 0.412 & 0.600 & Valid \\
18 & 0.361 & 0.613 & 0.571 & Valid \\
19 & 0.361 & 0.643 & 0.378 & Valid \\
20 & 0.361 & 0.739 & 0.572 & Valid \\
& & & & \\
\hline
\end{tabular}

Table 5 Reliability test result

\begin{tabular}{|ccc|}
\hline Questionnaire & Cronbach's Alpha & Status \\
\hline Expectation & 0.881 & Reliable \\
\hline Performance & 0.909 & Reliable \\
\hline
\end{tabular}

\subsection{Pertamax Customer Characteristics}

From the questionnaires that were distributed to 100 respondents, the information regarding Pertamax customer characteristics in Semarang City are generated. From table 6 and table 7, the information that can be derived is that the majority of Pertamax customer was female whose age between 17 years old and 27 years old and worked as entrepreneur.

Table 6 Pertamax customer characteristics based on gender and age

\begin{tabular}{|cccc|}
\hline Age & \multicolumn{2}{c}{ Gender } & \multirow{2}{*}{ Total } \\
\cline { 2 - 3 } (years old) & Female & Male & \\
\hline $17-27$ & 55 & 30 & 85 \\
$28-38$ & 5 & 10 & 15 \\
Total & 60 & 40 & 100 \\
\hline
\end{tabular}

Table 7 Pertamax customer characteristics job type

\begin{tabular}{|cc|}
\hline Job & Total \\
\hline College student & 31 \\
Entrepreneur & 36 \\
Civil servant & 19 \\
Others & 14 \\
\hline
\end{tabular}




\subsection{Customer Satisfaction Based on IPA Method}

Analysis of the level of customer satisfaction can be seen through the index of customer satisfaction on the actual performance of Pertamax and the index of customer expectations in using pertamax

Table 8 Pertamax customer satisfaction

\begin{tabular}{|cccc|}
\hline Item & $\begin{array}{c}\text { Actual } \\
\text { Performance }\end{array}$ & Expectation & Level \\
\hline 1 & 4.44 & 4.61 & $96 \%$ \\
2 & 4.50 & 4.56 & $99 \%$ \\
3 & 4.20 & 4.09 & $100 \%$ \\
4 & 3.79 & 4.18 & $91 \%$ \\
5 & 3.22 & 4.22 & $76 \%$ \\
6 & 4.14 & 4.52 & $92 \%$ \\
7 & 4.61 & 4.50 & $100 \%$ \\
8 & 4.36 & 4.40 & $99 \%$ \\
9 & 4.16 & 4.31 & $96 \%$ \\
10 & 4.19 & 4.30 & $99 \%$ \\
11 & 4.07 & 4.40 & $93 \%$ \\
12 & 4.31 & 4.37 & $99 \%$ \\
13 & 3.60 & 4.33 & $85 \%$ \\
14 & 3.96 & 4.59 & $86 \%$ \\
15 & 4.42 & 4.62 & $96 \%$ \\
16 & 4.12 & 4.61 & $89 \%$ \\
17 & 4.41 & 4.39 & $100 \%$ \\
18 & 4.28 & 4.30 & $99 \%$ \\
19 & 4.24 & 3.89 & $100 \%$ \\
20 & 4.34 & 4.47 & $98 \%$ \\
Total & 83.36 & 95.97 & $87 \%$ \\
\hline
\end{tabular}

Based on the information derived from table VIII, the customer satisfaction on using Pertamax is $87 \%$. This means that customers were very satisfied on using Pertamax. The most satisfying performance for customers was the ease in getting Pertamax since Pertamax can be found at every fuel station. Meanwhile, the one that is really expected by Pertamax customers was the ease of making payment at fuel stations.

Cartesian diagram quadrant was used to determine the Pertamax quality indicators that are satisfactory and unsatisfactory for customers. With the value of $\overline{\bar{X}}=4.618$ and $\overline{\bar{Y}}=4.3885$, the classification of Pertamax quality indicators can be determined as shown in figure 2 and table IX.

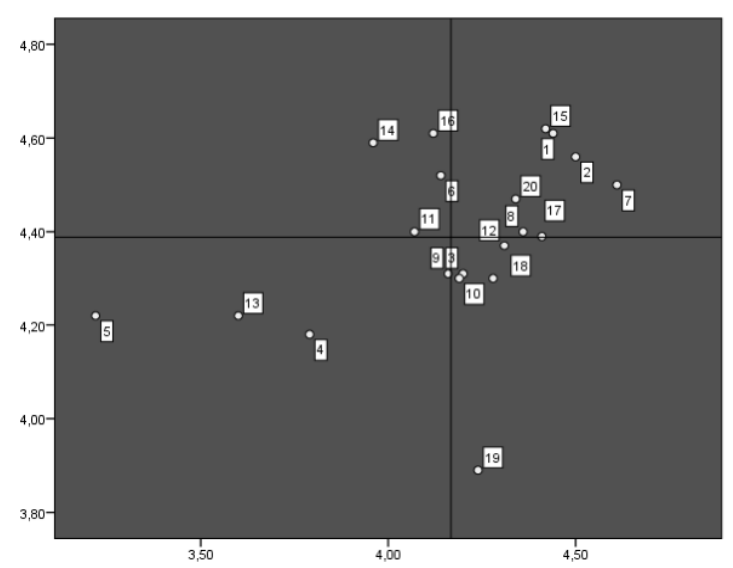

Figure 2 Pertamax Quality Classification - IPA Method

The first quadrant contains indicators that are considered important by customers, but the realization of company performance according to the customers does not meet customer expectation [7]. The company needs to focus on improving the indicators in this quadrant so that the customers will not leave the company when new competitors emerge. According to the information provided in table IX, the fuel station service, the evidence that Pertamax works well since the first use of Pertamax, and the efficiency of using Pertamax are considered important for customers, however customers measure that Pertamina needs to improve those indicators to meet the customer expectation. Therefore, it is necessary for Pertamina to implement following strategies:

a. Prove the quality of Pertamax to the public so that people believe more that Pertamax provides benefits for vehicle engines from the first use of Pertamax. The evidence should be published to the public so that people become aware that Pertamax has higher quality than Premium and Pertalite.

b. Promote that Pertamax has higher efficiency than Premium and Pertalite due to higher specifications that Pertamax has. The promotion can be done through the use of social media and mouth by mouth publication.

c. Improve the services provided by fuel stations operators and managements by holding training regarding how to service politely, friendly, and responsively to the customers.

The second quadrant consists of the indicators that are considered important by customers and the company is able to meet customer expectation. Under this circumstance, the company should keep the good work [7]. Table 9 provides the information that customers measure that Pertamax has a good effect on their vehicle engines, Pertamax is easy to be find in every fuel stations, Pertamax payment can be easily conducted in the fuel stations, Pertamax is easy to distinguish from other products, and Pertamax is able to make comfort for its users. Pertamina then should consider about these good works and continue to maintain those Pertamax's strong points. 
Table 9 Classification of pertamax quality - IPA method

\begin{tabular}{|lcl|}
\hline Quadrant & Item & \\
\hline Quadrant I & 6 & The benefit of Pertamax can be seen since the first use \\
(Concentrate & 11 & Pertamax is more efficient than Premium and Pertalite \\
Here) & 14 & Fuel station operators are polite and friendly \\
\hline & 16 & Fuel station operators are responsive in serving their customers \\
Quadrant II & 1 & Pertamax is able to maximize vehicle engines performance \\
(Keep Up & 2 & Pull of vehicle engine using Pertamax feels lighter and smoother compared to using Pertalite and Premium \\
the Good & 8 & Pertamax is easily found in every fuel station \\
Work) & 15 & Vehicle engines using Pertamax are cleaner than those using Pertalite and Premium \\
& 17 & The blue color of Pertamax make it easy to distinguish Pertamax from other products \\
& 20 & Pertamax creates comfort for its users \\
\hline Quadrant III & 4 & The use of Pertamax creates less expenditure for purchase and engine service costs. \\
(Low & 5 & Information regarding Pertamax specification and benefit can be easily found. \\
Priority) & 9 & Pertamax is more environmentally friendly compared to Pertalite and Premium \\
& 13 & Customer care provides well services to the customers \\
\hline & 3 & A long queue occurs in purchasing Pertamax at fuel stations \\
Quadrant IV & 10 & RON 92 influences the performance of vehicle engines \\
(Possible & 12 & The engine emissions produced by Pertamax are cleaner than Pertalite and Premium \\
Overkill) & 18 & The color of Pertamax is clear \\
& 19 & Pertamax is able to create pride for the customers \\
\hline
\end{tabular}

The third quadrant consists of the indicators that are not considered important by customers and the actual performance of these indicators, based on customer perception, is not the focus of the customers. As shown in table IX, costumers have little understanding that the use of Pertamax is able to save fuel and service costs. One function of RON is to fasten combustion process in the engine so that knocking can be avoided. The faster and well-run combustion will affect in the efficiency of Pertamax usage. In addition, customers also have little knowledge that Pertamax is environmentally friendly fuel and Pertamina has customer care where customers are able to make complaints.

The last quadrant consists of the indicators that are not considered important by customers, but the company emphasizes their focus on running these indicators. The indicators included in this quadrant are shown at table IX. Based on the survey to the respondents, respondents understand that Pertamax makes them comfort with their vehicle engines, however customers have little horizons about what factors that make Pertamax is capable of working effectively.

\section{CONCLUSION}

The Importance Performance Analysis is useful method to determine level of customer satisfaction on product quality and strategies that are needed to develop the quality. Based on the result of the research, it can be concluded that Pertamax customers are very satisfied with the quality of Pertamax with the level of satisfaction arrives at $87 \%$. However, some strategies are required to improve Pertamax quality since customers perceive that few qualities are under customer expectation. The one that should be conducted by Pertamina is to socialize the benefit of using Pertamax so that people are aware with those benefits since the first use. It is also advisable to increase the services provided by fuel station management and operators.
Some limitations are found in this research due to the use of survey as the only method to collect data. There are some difficulties in controlling whether the answers given by respondents were appropriate with the true condition. In addition, respondents did not have much time to fill out questionnaires because it might lengthen the Pertamax filling queue. Therefore it is advisable to the next research to use additional methods to measure customer satisfaction, such as lost customer analysis.

\section{REFERENCES}

[1] F. Tjiptono and G. Chandra, Pemasaran Strategik, Yogyakarta: Penerbit Andi, 2012.

[2] A.R. Amelia, "44 persen pengguna premium beralih ke pertalite dan pertamax," unpublished.

[3] Febrina, "Pertamina berharap konsumen tetap loyal menggunakan pertamax", unpublished.

[4] A. Arvirianti, "Perhatian, pertamax naik harga hari ini jadi Rp 10.400”, unpublished.

[5] M.N. Asikin, "Masyarakat ternyata lebih kecewa pertamax naik", unpublished.

[6] R. Lupiyoadi, and R.B. Ikhsan, Praktikum Metode Riset Bisnis, Jakarta: Salemba Empat, 2013.

[7] J.A. Martilla, and J.C. James, "Importance performance analysis", Journal of Marketing, vol.4, issue 1, pp. 77-79, 1977.

[8] Sugiyono, Metode Penelitian Kuantitatif, Kualitatif, dan R\&D, Bandung: Alfabeta, 2009. 